\title{
ECONOMIC ASSESSMENT OF THE INVESTMENT CLIMATE IN THE PROCESS OF ENSURING SUSTAINABLE DEVELOPMENT OF UKRAINE
}

\author{
Kostiantyn Shaposhnykov', Kateryna Okayanyuk ${ }^{2}$
}

\begin{abstract}
The purpose of the article is a systemic economic analysis of the investment climate in the process of ensuring sustainable development of Ukraine. European integration strategy of Ukraine necessitates the formation of an investment climate in order to adapt to European requirements, create a development strategy to integrate with developed countries, harmonize economic trade and environmental processes. Methodology. In the course of this analysis, the investment climate was considered as a complex open system with the application in the study of the methodology of systemic analysis, which allowed to emphasize certain aspects of the specific nature of its operation. Results. It is established that in modern conditions of acceleration of transformation processes the mechanisms of expansion of investment opportunities and overcoming of investment restrictions at all levels of hierarchy of taxonomic systems are characterized by any importance and intensity. At the global level, this affects the international movement of capital and the formation of world investment wealth through the internationalization of the economies of different countries. At the national level, this applies to regulatory and legal support, formation of institutional support for investment processes, diversification of ownership, sources and types of investment resources. At the local and territorial levels, it is especially important to ensure investment in human capital and the social sphere.

The factors of negative influence on the development of Ukrainian industry are determined: reduction of world prices for ferrous metals; national gaps in the development of railway transport causing problems with logistics; the need to repair production facilities in the fields of metallurgy, electricity, gas and steam, carbonite and refining; low level of yield in agriculture (for the food industry); sanctions of the Russian Federation; inflation; reduction in use of electricity and gas due to global warming; market advantage of imports of competitive products. The priority tasks for the development of Ukrainian industry are also outlined: renewal of industrial production facilities; development of infrastructure and logistics; balancing of external and internal market conditions; providing the food industry by increasing the volume of agricultural production; ensuring the purchasing power of domestic consumers and expanding demand.

It is established that the level of capital investments in the first half of 2020 lags significantly behind the previous year. In addition, with the development of the COVID-19 pandemic in 2020, the situation with the inflow of foreign direct investment in Ukraine has also deteriorated significantly. According to preliminary results, the balance of FDI amounted to $-112.6 \%$. This was not the case even in the unfavorable economic development of 2014, which was characterized as a crisis period associated with the military conflict in the east and the annexation of Crimea. Practical implications. The analysis of the peculiarities of the investment climate and its goals allows to determine the role of investment in achieving the Sustainable Development Goals by 2030, to identify key priorities in solving environmental problems, to form the potential for sustainable development. For Ukraine, these are components of the formation of the investment climate in a pandemic. Value/originality. The use of systems analysis allows to identify the main problems of formation of the investment climate in modern conditions.
\end{abstract}

Key words: investment climate, the COVID-19 pandemic, sustainable development goals, industry, economic evaluation, systemic analysis.

JEL Classification: R11, R42, R50

\footnotetext{
Corresponding author:

${ }^{1}$ Black Sea Research Institute of Economy and Innovation, Ukraine.

E-mail: k.s.shaposhnykov@gmail.com

ORCID: https://orcid.org/0000-0003-0640-9934

${ }^{2}$ Black Sea Research Institute of Economy and Innovation, Ukraine.

ORCID: https://orcid.org/0000-0003-0231-9165
} 


\section{Introduction}

The problem of forming an investment climate at the national level is objectively considered to be the starting point in the study of issues of state regulation of the national economy. In modern conditions of accelerating transformation processes, the mechanisms of expanding investment opportunities and overcoming investment constraints at all levels of the hierarchy of taxonomic systems are characterized by some importance and intensity. At the global level, this affects the international movement of capital and the formation of world investment wealth through the internationalization of the economies of different countries. At the national level, this applies to regulatory and legal support, the formation of institutional support for investment processes, diversification of ownership, sources and types of investment resources. At the local and territorial levels, it is especially important to ensure investment in human capital and the social sphere.

The formation of the investment climate of the state cannot be considered a discrete or momentary phenomenon, because this process is permanent and rather characterized by continuity. At the present stage of economic development of Ukraine, there is often a problem of limited investment resources and opportunities for their reproduction, which is accompanied by the peculiarities of financial capacity and institutional support and, as a result, income generation opportunities and economic efficiency.

That is why studies of the peculiarities of state regulation of the national economy in terms of investment restrictions remain relevant. An important role remains in the economic assessment of the current state of the investment climate in Ukraine.

Many prominent domestic specialists, including I. Blank, V. Heiets, A. Hrytsenko, I. Irtyshcheva, V. Kyrylenko and others, as well as foreign researchers - G. Birman, L. Gitman, D. Keynes, A. Marshall, S. Fisher, S. Schmidt and others, dealt with the issues of investment climate and investment potential.

\section{Sustainable Development Strategy for Ukraine by 2030}

Weaker national economies are at risk of resource depletion, increasing their dependence on the world's highly developed nations and, as a result, deteriorating domestic economic conditions. That is why it is important for all countries of the world economic space to adhere to the principles and goals of sustainable development (Figure 1), which were adopted in 2015 in the form of the 2030 Agenda at the global level by 193 countries.

"The Sustainable Development Goals are the blueprint to achieve a better and more sustainable future for all. They address the global challenges we face, including poverty, inequality, climate change, environmental degradation, peace and justice. The goals of sustainable development include a call for action by all countries - poor, rich, middle-income - to promote prosperity while protecting the planet. They recognize that poverty eradication goes hand in hand with strategies that deliver economic growth and meet a wide range of social needs, including education, health, social protection and employment opportunities, while addressing climate change and the environment. As never before, the goals provide a critical foundation for recovery from COVID-19" (Sustainable Development Goals, 2019).

Given the limited investment resources, in particularin the context of the COVID-19 pandemic, the issue of assessing the investment climate in Ukraine and the effective use of foreign investment is becoming extremely important.

According to the Economic strategy "Growth through investment", by 2024Ukraine will primarily grow investment in people and production, which should achieve GDP growth of $40 \%$ (Economic strategy "Growth through investment", 2020).

Observing the change in the numerical values of Ukraine's GDP, it is possible to determine the growth trend of this macroeconomic indicator for fifteen consecutive quarters. However, growth is accelerated or slowed down periodically. Thus, in the 3rd and 4th quarters of 2019, Ukraine's GDP growth slowed down, as in the 3rd quarter there was 4.1-times growth of this indicator, and in the 4th quarter of 2019 there was a 1.5-times growth. This slowdown in Ukraine's GDP growth was caused by the deterioration of industrial production and agriculture. In the fourth quarter of 2019, for the first time in three years, industrial output decreased, and due to high dependence on weather conditions, there was an early harvest of crops, and compared to previous high yields, there was a decrease in this indicator in agriculture. 

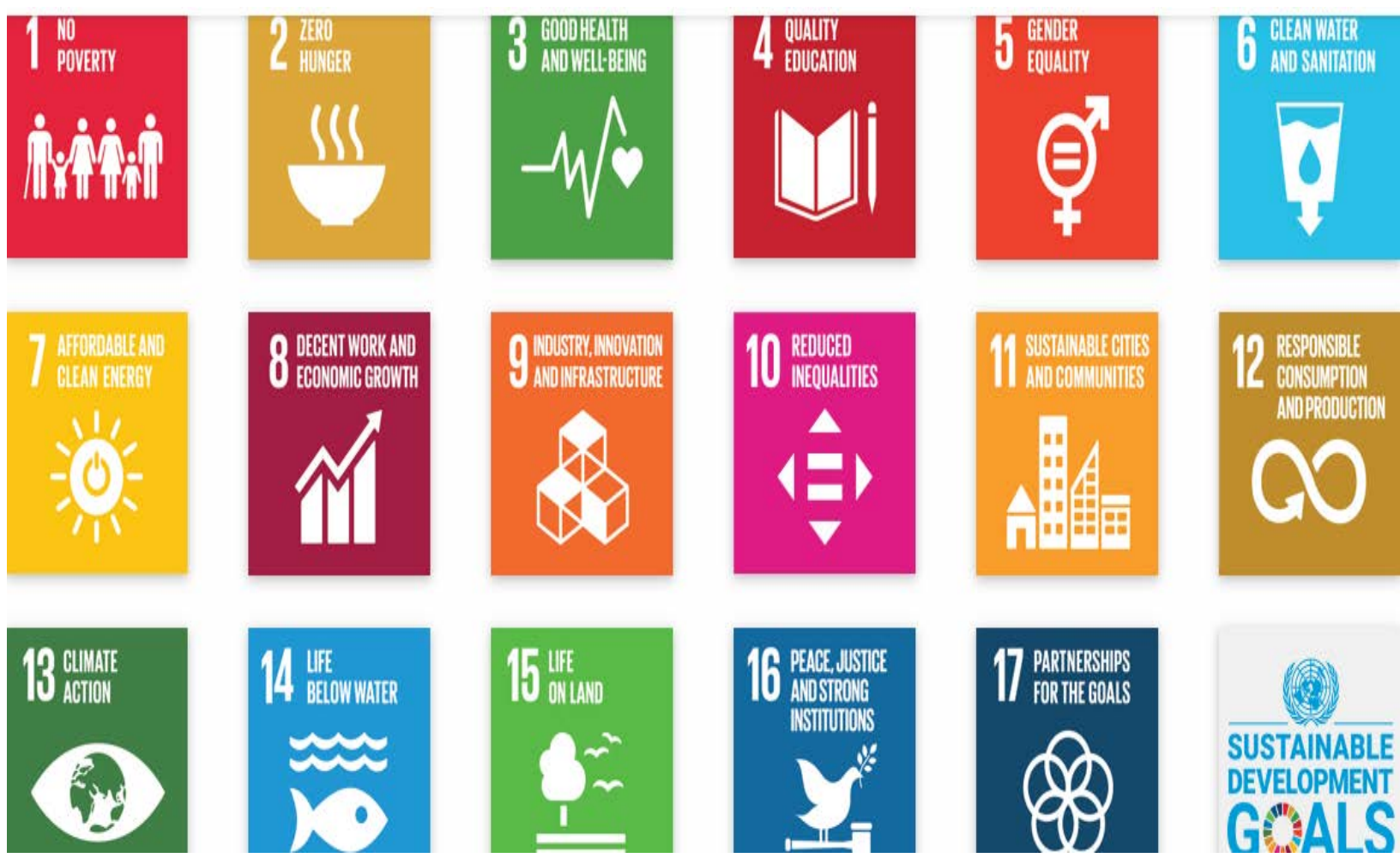

Figure 1. Global Sustainable Development Goals
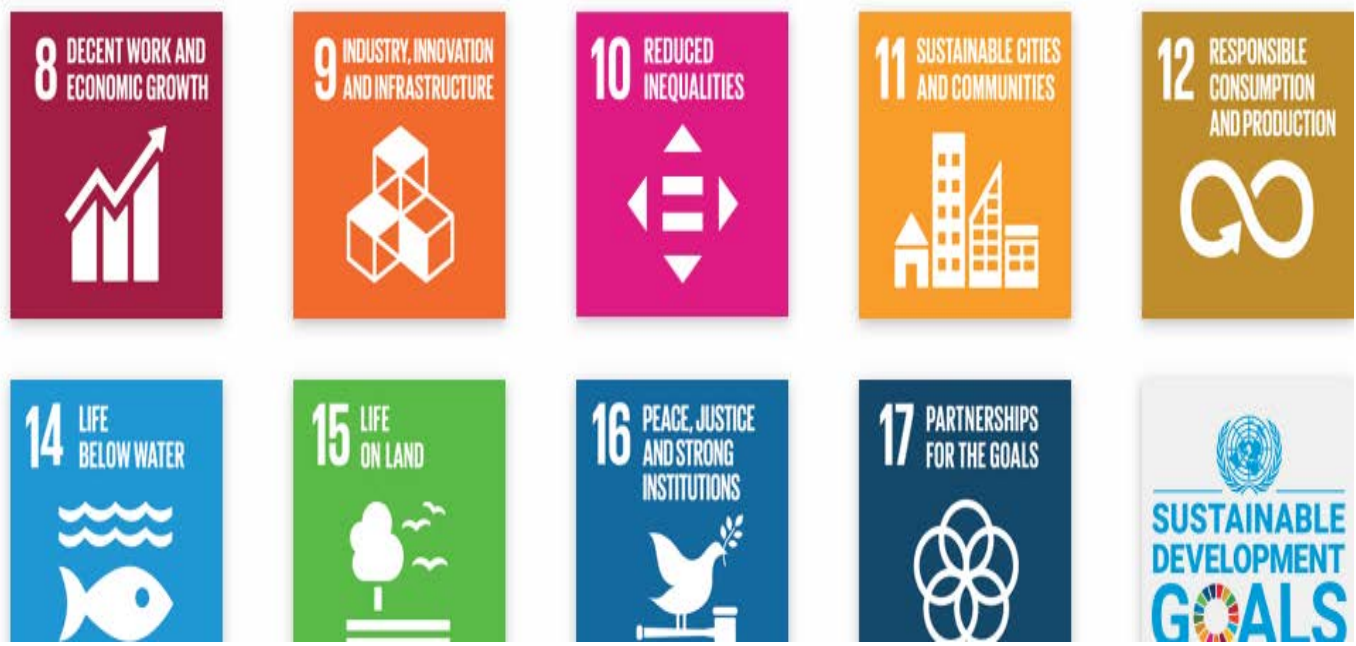

SUSTAINABLE DEVELOPMENT GOALS

Source: Sustainable development goals, Global Compact Network in Ukraine, 2019

\section{Development of industry as the main indicator of investment climate formation}

Industry, agriculture, transport and construction have the strongest influence on the formation of Ukraine's GDP. In 2019, according to the Ministry for Development of Economy, Trade and Agriculture of Ukraine, the index of industrial production as a whole was $-1.8 \%$, in the processing industry this figure was $-2 \%$, and in the supply of electricity, gas and steam it counted to $-4.1 \%$. In 2019, from all subsectors of industry, several demonstrated growth: pharmaceuticals, chemical and food industries, furniture, repair and installation of equipment. The mining industry did not show any changes, and all other subsectors were characterized by a decline (Table 1 ).

Table 1

Dynamics of the index of industrial production of Ukraine

\begin{tabular}{|l|c|c|}
\hline \multirow{2}{*}{ Industry (type of activity) } & \multicolumn{2}{c|}{ Industrial production index, \% } \\
\cline { 2 - 3 } & 2018 & 2019 \\
\hline Pharmaceuticals & 1.1 & 5.1 \\
\hline Chemical industry & 17.4 & 3.3 \\
\hline Furniture, repair and installation of equipment & 5.6 & 0.2 \\
\hline Food industry & -1.5 & 0.2 \\
\hline Mining industry & 2.4 & 0.0 \\
\hline Building materials & -0.5 & -0.7 \\
\hline Metallurgy & 0.6 & -3.1 \\
\hline Electricity, gas and steam supply & 2.8 & -4.1 \\
\hline Carbonite, oil refining & 3.5 & -5.1 \\
\hline Engineering & 1.6 & -5.6 \\
\hline Wood processing, pulp, printing industry & 2.5 & -5.8 \\
\hline Textile industry & -3.2 & -9.9 \\
\hline
\end{tabular}

Source: (State Statistics Service of Ukraine, 2020; Economic strategy "Growth through investment", 2020) 
In the processing industry, the strongest decline in 2019 occurred in the textile industry and amounted to $-9.9 \%$. The index of products of wood processing, pulp, printing industry was $-5.8 \%$, and in carbonite and oil refining $-5.1 \%$.

Having analyzed the dynamics of the index of industrial products of Ukraine and the peculiarities of the functioning of this industry, it is possible to identify factors of negative impact on its development:

- reduction of world prices for ferrous metals;

- national gaps in the development of railway transport causing problems with logistics;

- the need to repair production facilities in the fields of metallurgy, electricity, gas and steam, carbonite and refining;

- low level of yield in agriculture (for the food industry);

- sanctions of the Russian Federation;

- inflation;

- reduction in use of electricity and gas due to global warming;

- market advantage of imports of competitive products.

A clear delineation of the factors of negative impact makes it possible to identify priorities for the development of industry in Ukraine:

- renewal of industrial production facilities;

- development of infrastructure and logistics;

- balancing of external and internal market conditions;

- providing the food industry by increasing the volume of agricultural production;

- ensuring the purchasing power of domestic consumers and expanding demand.

With regard to the development of agriculture in Ukraine, it should be noted that in general there is also a tendency to increase production. However, this is mainly due to the high level of grain yields and growing demand for poultry products. Along with this, in 2019 there was a decrease in the volume of grown potatoes, sugar beets and fruit crops.

The increase in yields of cereals, sunflowers and individual vegetables was influenced by the following factors:

- increasing the size of sown areas for certain types of agricultural crops;

- increasing the yield of certain types of crops through the use of new technologies and favorable weather conditions, especially for late crops.

The dynamics of livestock development indicates an improvement in the situation with meat production for the period 2017-2019. The opposite situation with milk production, here the increase is changing downwards: from $-1.0 \%$ in 2017 to $-3.7 \%$ in 2019.

In recent years, the need to modernize production facilities and investment activity of most industrial enterprises has had a positive impact on the growth of production in the construction industry. In addition, capital expenditures of the State Road Fund have increased, as well as construction costs in the regions, and the capabilities of construction companies have expanded. Further development of transport infrastructure, social sphere facilities and continuation of modernization of production facilities of industrial enterprises is expected.

\section{Formation of the investment climate in the conditions of the COVID-19 pandemic}

Capital investment plays an important role in upgrading fixed assets and increasing production. "Investments in fixed capital (capital investments) include investments in capital construction, machinery, equipment, tools, inventory, vehicles and other fixed assets" (Capital investments. Methodological explanations, 2020). During January-June 2020, compared to the same period in 2019, the level of capital investment in Ukraine was slightly more than $60 \%$. The main reason for this decline is the crisis associated with COVID-19. 2020 can be considered a crisis due to the pandemic, and hope to maintain the previous trend of increasing investment inflows for 2018-2019 (Table 2).

Table 2

Dynamics of capital investments, \%

\begin{tabular}{|c|c|c|}
\hline Period & $\begin{array}{c}\text { Million } \\
\text { UAH }\end{array}$ & $\begin{array}{l}\text { \% to the } \\
\text { corresponding period } \\
\text { of the previous year }\end{array}$ \\
\hline \multicolumn{3}{|c|}{2018} \\
\hline January-March & 88955.1 & 137.4 \\
\hline January-June & 206893.6 & 126.5 \\
\hline January-September & 337045.6 & 119.9 \\
\hline January-December & 526341.8 & 116.4 \\
\hline \multicolumn{3}{|c|}{2019} \\
\hline January-March & 108298.0 & 117.8 \\
\hline January-June & 233995.5 & 112.3 \\
\hline January-September & 379203.1 & 112.3 \\
\hline January-December & 584448.6 & 115.5 \\
\hline \multicolumn{3}{|c|}{2020} \\
\hline January-March & 76914.3 & 64.5 \\
\hline January-June & 163781.5 & 65.1 \\
\hline
\end{tabular}

Source: (Socio-economic development of Ukraine, 2020) 
In the first half of 2020, only some regions of Ukraine (Volyn, Poltava, Kirovohrad) managed to approach last year's capital investment.

Along with the problem of the pandemic in the first half of 2020, Ukraine still needed to restore the infrastructure of the east of the country. "Today, the need for a potential restoration of eastern Ukraine has been added to the traditional infrastructural problems. However, there are some problems in public investment management in Ukraine. There are many examples of public investment projects that do not help economic growth in any way, but on the contrary, become a symbol of corruption and inefficiency of government actions" (Fedorchak, 2017).

The dynamics of the regional distribution by level of capital investment shows that in the period 2010-2019 the leaders in terms of capital investment were Dnipropetrovsk and Kyiv regions. In 2019, the highest level of capital investment was in Dnipropetrovsk region and amounted to 66,951.1 million UAH. Kyiv region with a capital investment of 50,295.7 million UAH was in the second place. At the bottom of this rating there were Luhansk region, where capital investments amounted to 3,357.5 million UAH, and Chernivtsi region, where capital investments amounted to 4,096.8 million UAH.

The dynamics of capital investment in 2010-2019 in Ukraine as a whole, except for 2014 (the beginning of hostilities in the east), shows growth. However, given the significant lag in the level of capital investment in the first half of 2020 from the previous year, there are doubts whether such positive dynamics will continue in the future.
To upgrade fixed assets and increase production, it is important to attract foreign direct investment, which is considered the most effective form of investment for a developing economy. Foreign direct investment provides an opportunity to implement new projects, master new technologies and practices of corporate governance. However, despite the improvement of the investment climate in Ukraine, Ukraine ranks lowest among neighboring countries in terms of foreign direct investment (FDI) per capita. Compared to Slovakia, the level of FDI per capita in Ukraine is almost eleven times lower.

Given the development of the COVID-19 pandemic in 2020, the situation with the inflow of foreign direct investment in Ukraine has significantly deteriorated. The balance of FDI according to preliminary results amounted to $-112.6 \%$. This was not the case even in the unfavorable economic development of 2014, which was characterized as a crisis period associated with the military conflict in the east and the annexation of Crimea (Table 3).

The dynamics of changes in foreign direct investment for Ukraine does not show any patterns. The levels of the series fluctuate in the direction of growth, then in the direction of decline. Therefore, it is impossible to predict any objective forecasts.

The situation with the possibility of forecasting the economic development of Ukraine is complicated by the spread of the COVID-19 pandemic. However, the National Bank of Ukraine provides quite comforting forecasts for overcoming the COVID-19 crisis, noting that "We are going through this crisis much better than the previous ones. The products of our

Table 3

Dynamics of foreign direct investment in Ukraine (million USD)

\begin{tabular}{|c|c|c|c|c|c|c|}
\hline \multirow{2}{*}{ Year } & \multicolumn{2}{|c|}{ FDI to Ukraine } & \multicolumn{2}{|c|}{ FDI from Ukraine } & \multirow{2}{*}{ Balance } & \multirow{2}{*}{ Growth, \% } \\
\hline & million USD & Absolute growth & million USD & Absolute growth & & \\
\hline 2010 & 6495 & +1679 & 736 & +574 & +5759 & $+23.7 \%$ \\
\hline 2011 & 7207 & +712 & 192 & -544 & +7015 & $+21.8 \%$ \\
\hline 2012 & 8401 & +1194 & 1206 & +1014 & +7195 & $+2.6 \%$ \\
\hline 2013 & 4499 & -3902 & 420 & -786 & +4079 & $-43.3 \%$ \\
\hline 2014 & 410 & -4089 & 111 & -309 & +299 & $-92.7 \%$ \\
\hline 2015 & 2961 & +2551 & -51 & -162 & +3012 & $+907.4 \%$ \\
\hline 2016 & 3284 & +323 & 16 & +67 & +3268 & $+8.5 \%$ \\
\hline 2017 & 2202 & -1082 & 8 & -8 & +2194 & $-32.9 \%$ \\
\hline 2018 & 2355 & +153 & -5 & -13 & +2360 & $+7.6 \%$ \\
\hline 2019 & 3070 & +715 & 648 & +653 & +2422 & $2.6 \%$ \\
\hline 2020 & -294 & -3364 & 10 & -638 & -304 & $-112.6 \%$ \\
\hline
\end{tabular}

Source: calculated on the basis of data from the Ministry of Finance of Ukraine (Foreign direct investment in Ukraine, 2020) 
exporters - metallurgists, farmers, programmers sold relatively well in other countries. The banking system worked smoothly. The government settled its debts on time. There was no inflation surge" (Simply about economy, 2020).

According to experts of the National Bank of Ukraine: "As a result of the pandemic in 2020, Ukraine's economy will shrink by about $6 \%$. This indicator is the "mean temperature" for European countries. For example, the contraction of the EU economy is likely to be over $7 \%$. All countries have suffered significant losses from the pandemic and Ukraine is no exception. We are going through this crisis much better than the previous ones. The products of our exporters - metallurgists, farmers, programmers - sold relatively well in other countries. The banking system worked smoothly. The government settled its debts on time. There was no inflation surge." (Simply about economy, 2020).

According to the same assessment of the NBU, against the background of the estimated value of the level of price growth in 2020 at $4.1 \%$, the peak growth of consumer prices is projected for 2021 $6.5 \%$, and in 2022 price growth should be $5.0 \%$. The unemployment rate in 2019 is $8.2 \%$, and the projected values for $2020-9.4 \%, 2021-8.6 \%$, $2022-8.6 \%$ (Simply about economy, 2020).

Economicrecovery will contribute to employment and improve living standards in Ukraine. However, a necessary condition for business development and boosting the development of leading sectors of the economy is the emergence of effective drugs against COVID-19.

\section{Conclusions}

It is established that in modern conditions of acceleration of transformation processes, the mechanisms of expansion of investment opportunities and overcoming of investment restrictions at all levels of hierarchy of taxonomic systems are characterized by any importance and intensity. At the global level, this affects the international movement of capital and the formation of world investment wealth through the internationalization of the economies of different countries. At the national level, this applies to regulatory and legal support, the formation of institutional support for investment processes, diversification of ownership, sources and types of investment resources. At the local and territorial levels, it is especially important to ensure investment in human capital and the social sphere.

Against the background of GDP growth in Ukraine for fifteen consecutive quarters (2nd quarter of 2016 - 4th quarter of 2019), it was found that in different periods the growth was accelerated or slowed down. Thus, in the 3rd and 4th quarters of 2019, Ukraine's GDP growth slowed down, as in the 3 rd quarter there was 4.1-times growth of this indicator, and in the 4th quarter of 2019 there was a 1.5-times growth. This caused by the deterioration of industrial production and agriculture. In the 4th quarter of 2019 , for the first time in three years, industrial output decreased, and due to high dependence on weather conditions, there was an early harvest of crops, and compared to previous high yields, there was a decrease in this indicator in agriculture.

The factors of negative influence on the development of Ukrainian industry are determined: reduction of world prices for ferrous metals; national gaps in the development of railway transport causing problems with logistics; the need to repair production facilities in the fields of metallurgy, electricity, gas and steam, carbonite and refining; low level of yield in agriculture (for the food industry); sanctions of the Russian Federation; inflation; reduction in use of electricity and gas due to global warming; market advantage of imports of competitive products. The priority tasks for the development of Ukrainian industry are also outlined: renewal of industrial production facilities; development of infrastructure and logistics; balancing of external and internal market conditions providing the food industry by increasing the volume of agricultural production; ensuring the purchasing power of domestic consumers and expanding demand.

It is established that the level of capital investments in the first half of 2020 has lagged significantly behind the previous year. In addition, with the development of the COVID-19 pandemic in 2020, the situation with the inflow of foreign direct investment in Ukraine has also deteriorated significantly. The balance of FDI according to preliminary results amounted to $-112.6 \%$. This was not the case even in the unfavorable economic development of 2014, which was characterized as a crisis period associated with the military conflict in the east and the annexation of Crimea. 


\section{References:}

Sustainable development goals (2019). Available at: https://www.un.org/sustainabledevelopment/ sustainable-development-goals/ (accessed 10 September 2020).

Sustainable development goals. Global Compact Network in Ukraine (2019). Available at: https://globalcompact.org.ua/pro-nas/tsili-stijkogo-rozvytku/ (accessed 10 September 2020).

Economic strategy "Growth through investment" (2020). Available at: https://drive.google.com/file/ d/1DmerrNq53rk4PixQRvCTgatC08YgFMW/view (accessed 10 September 2020).

State Statistics Service of Ukraine (2020). Available at: http://www.ukrstat.gov.ua/ (accessed 10 September 2020).

I. Irtyshcheva, I. Kramarenko, S. Shults, Y. Boiko, K. Blishchuk, N. Hryshyna, N. Popadynets, I.Dubynska, O. Ishchenko and D. Krapyvina (2020). Building favorable investment climate for economic development. Accounting, vol. 6, no. 5, pp. 773-780.

Capital investments. Methodological explanations (2020). Available at: http://www.ifstat.gov.ua/ STAT/m_inv.htm (accessed 10 September 2020).

Socio-economic development of Ukraine (2020). State Statistics Service of Ukraine. Available at: http://www.ukrstat.gov.ua/operativ/infografika/2020/soc_ek_r_Ukr/soc_ek_r_Ukr_09_2020.pdf (accessed 10 September 2020).

Fedorchak, O.V. (2017). Problems of public investment in Ukraine. Bulletin of the National Academy of Sciences of Ukraine under the President of Ukraine, no. 4, pp. 45-55. (in Ukrainian)

I. Kramarenko, I. Irtyshcheva, S. Shults, M. Stegney, B. Kateryna, Y. Boiko, N. Popadynets, N. Samotiy, L. Rogatina and N. Hryshyna (2020). An economic management system for sustainable development in black sea region. Accounting, vol. 6, no. 4, pp. 387-394.

Simply about economy (2020). National Bank of Ukraine. Available at: https://bank.gov.ua/ua/news/ all/prosto-pro-ekonomiku-za-materialami-inflyatsiynogo-zvitu-za-jovten-2020-roku (accessed $10 \mathrm{Sep}$ tember 2020).

Kramarenko, I. S., Irtyshcheva, I. O., Senkevich, O. F., Topchiy, O. O., \& Voit, D. S. (2020). Structural and dynamic characteristics of investment resources of regions. Effective Economy, no. 3. Available at: http://www.economy.nayka.com.ua/pdf/3_2020/82.pdf (accessed 10 September 2020). (in Ukrainian) Foreign direct investment in Ukraine (2020). Ministry of Finance of Ukraine. Available at: https://index.minfin.com.ua/en/economy/fdi/ (accessed 10 September 2020). 